\title{
Local biochronology of Middle and Late Pleistocene mammals from the Caucasus
}

\author{
Gennady F. Baryshnikov
}

\begin{abstract}
The seven faunal units (Akhalkalaki, Urup, Kudaro, Kvaisi, Binagady, Chasovali, Akhstyr) are recognized for the Caucasian Middle and Late Pleistocene mammals for the first time. These local groups correlate to the middle and late Galerian and Aurelian Mammal Ages in Western Europe. There are differences between species composition in the Transcaucasian localities, comprising warm-requiring and forest species and that in the Northern Caucasian localities, containing steppe and boreal species.
\end{abstract}

KEY-WORDS. Continental biochronology, Pleistocene, mammals, Caucasus.

Gennady F. Baryshnikov [G_Baryshnikov@mail.ru], Zoological Institute, Russian Academy of Sciences, Universitetskaya nab. 1, 199034 Saint Petersburg, Russia.

\section{Локальная биохронология средне- и позднеплейстоценовых млекопитающих Кавказа}

\section{Г.Ф. Барышников}

\begin{abstract}
РЕЗЮМЕ. Впервые выделены семь локальных фаунистических комплексов (Ахалкалакский, Урупский, Кударский, Квайсинский, Бинагадинский, Часовальский, Ахштырский) для млекопитающих среднего и позднего плейстоцена Кавказа. Проведена их корреляция с одновозрастными группировками млекопитающих Западной Европы. На Кавказе в плейстоцене наблюдаются различия в видовом составе между териофауной Закавказья и Северного Кавказа; в западном Закавказье преобладали теплолюбивые горные и лесные виды, на Северном Кавказе были обычнее степные и бореальные виды.
\end{abstract}

КЛЮЧЕВЫЕ СЛОВА. Континентальная биохронология, плейстоцен, млекопитающие, Кавказ.

\section{Introduction}

In the Caucasus the Middle and Late Pleistocene mammals were found mainly at archaeological excavations in caves and open-air sites situated from foot hills to height more than $2000 \mathrm{~m}$ above sea level (a.s.1.). Several large mammal remains (especially proboscides) came from localities, which were formed without activity of ancient man (alluvial deposits and asphalt pits).

In the Pleistocene, the forest area of the Transcaucasia has been a refuge for some species, which survived there for a longer time than in Europe (Guérin \& Barychnikov, 1987; Baryshnikov, 1989; Guérin et al., 1992). This situation complicates biochronological correlation for the Pleistocene mammals in the Caucasus. Therefore, for these procedures, the additional information on geomorphology of the river terraces, archaeological facts, scarce radiometric and palaeomagnetic dating and palynology data are desirable. Recently Nesmeyanov (1999) summarized such information for the Paleolithic sites in the Western Caucasus.

The paper provides the preliminary attempt to create a detailed chronological scale, based mainly on the mammals from the Paleolithic multilayer cave sites. Here I used for the first time for the Caucasus the faunal units (F.U.), similar to that elaborated for the faunal successions in Italy (Azzaroli et al., 1982).

Stratigraphic position of the most significant Caucasian localities is shown in the Table. Biochronological scale was associated with the available oxygen isotope stages (Shackleton \& Opdyke, 1976; Shackleton, 1995). The boundary between the Early and Middle Pleistocene is placed close to isotopic stage 25 , the boundary between the Middle and the Late Pleistocene is placed at isotopic stage 5e (Aguirre \& Pasini, 1985; Gliozzi et al., 1997).

The large and small mammal species lists are given for the type localities of the each faunal unit, and species not found at the type localities are additionally listed for both Transcaucasia and Northern Caucasus.

\section{Large mammals}

\section{Galerian Mammal Age}

Middle and late Galerian assemblage corresponds to the Tiraspolian and early Singilian middle Pleistocene mammal complexes in Eastern Europe (Alexeeva, 1977). In the Caucasus, the first half Middle Pleistocene fauna is represented by the Akhalkalaki locality situated at height 1700 m a.s.1. near Akhalkalaki City in Georgia. 
Table. Chronological position of the main middle and lower Pleistocene localities in the Caucasus.

\begin{tabular}{|c|c|c|c|c|c|c|}
\hline \multirow{2}{*}{$\begin{array}{l}\text { Time, } \\
\text { MA }\end{array}$} & \multirow{2}{*}{$\begin{array}{c}\text { Oxygen } \\
\text {-Isotope } \\
\text { Stage }\end{array}$} & \multicolumn{2}{|c|}{ Mammal Ages } & \multirow{2}{*}{$\begin{array}{l}\text { Faunal } \\
\text { Units }\end{array}$} & \multicolumn{2}{|c|}{ Localities } \\
\hline & & $\begin{array}{l}\text { Western } \\
\text { Europe }\end{array}$ & $\begin{array}{l}\text { Eastern } \\
\text { Europe }\end{array}$ & & Transcaucasia & Northem Caucasus \\
\hline \multirow[t]{2}{*}{0.025} & 2 & \multirow{12}{*}{ Aurellian } & \multirow[t]{2}{*}{ Sungilian } & Akhstyr & $\begin{array}{c}\text { Akhstyrskaya Cave (layer 2), Kudaro } \\
3 \text { (layer 2), Gvardzhilas-KIde }\end{array}$ & $\begin{array}{c}\text { Matuzka (layer 2), Gubs Shelter } \\
\text { 1, Satanai }\end{array}$ \\
\hline & 3 & & & \multirow{3}{*}{ Chasovali } & Kudaro 3 (layer 3) & Mezmaiskaya Cave (layers 2-3) \\
\hline 0.073 & 4 & & \multirow{3}{*}{ Shkurlatian } & & Kudaro 3 (layers 4a-4e), & $\begin{array}{c}\text { Ilskaya } 2 \text { (layers 5-6), Matuzka } \\
\text { (lavers 5-5b) Barakaevskava Cave }\end{array}$ \\
\hline 0.116 & $5 a-5 d$ & & & & (layer 4), Bisonova, Erevan, Taglar & Mezmaiskaya Cave (layers 2-3) \\
\hline 0.128 & $5 e$ & & & Binagady & Binagady, Kudaro 3 (layer 4f) & Girei, Matuzka (layer 6) \\
\hline 0.195 & 6 & & \multirow{3}{*}{ Khazarian } & \multirow{3}{*}{ Kvaisi } & & Matuzka (layer 7) \\
\hline \multirow{2}{*}{0.251} & 7 & & & & Kudaro 3 (layer 5) & \\
\hline & 8 & & & & & \\
\hline \multirow{2}{*}{0.367} & 9 & & \multirow{7}{*}{ Singillian } & \multirow{3}{*}{ Kudaro } & Kudaro 1 (layer 5b) & \\
\hline & 10 & & & & Kudaro 1 (layer 5c), Leninakan & Treugolnaya Cave (layers 5a-5b) \\
\hline \multirow[t]{3}{*}{0.440} & 11 & & & & & Treugolnaya Cave (layer 5c) \\
\hline & 12 & & & \multirow{4}{*}{ Urup } & & \\
\hline & 13 & \multirow{7}{*}{ Galerian } & & & \multirow{3}{*}{ Azykh (layer 6) } & \multirow{3}{*}{ Treugolnaya Cave (layers 6-7) } \\
\hline 0.542 & 14 & & & & & \\
\hline \multirow[t]{3}{*}{0.592} & 15 & & & & & \\
\hline & $16-18$ & & \multirow{4}{*}{ Tiraspolian } & & & \\
\hline & $18-20$ & & & & & \\
\hline \multirow[t]{2}{*}{0.782} & 21 & & & \multirow{2}{*}{$\begin{array}{l}\text { Akhal- } \\
\text { kalaki }\end{array}$} & \multirow{2}{*}{ Akhalkalaki, Azykh (layers 7-10) } & \\
\hline & 22 & & & & & \\
\hline
\end{tabular}

Akhalkalaki F.U. (stratum type - Akhalkalaki): Canis mosbachensis (= C. tengisii), Ursus deningeri, Lutra cf. lutra, Meles cf. meles, Vormela peregusna, Pachycrocuta brevirostris, Homotherium sp., Panthera gombaszogensis, Mammuthus meridionalis, Mammuthus trogontherii, Equus hipparionoides (close to E. altidens), Equus suessenbornensis, Stephanorhinus etruscus, Hippopotamus georgicus, Megaloceros solilhacus, Bos sp., Bison sp., ?Sinoreas sp., Capra sp. (Vekua, 1962, 1987, 1995; Azzaroli, 1983; Dzhaparidze et al., 1989; Baryshnikov \& Vereshchagin, 1996; Guérin, 1996).

Vekua $(1962,1987,1995)$ has attributed this fauna to the Tamanian mammals complex of the Early Pleistocene, however the presence ofMammuthus trogontherii as well as the genera Bos and Capra suggests a younger age for this fauna (Alexeeva, 1977).

In Italy, Pachycrocuta brevirostris reaches up to Slivia F.U., where both Mammuthus trogontherii and Bos galerianus were also recorded, while Megaloceros solilhacus was found for the first time only in Isernia F.U. (Petronio \& Sardella, 1999). Mazza (1991) noted the similarity of Hippopotamus georgicus with $\mathrm{H}$. antiquus, which existed in Europe up to Mosbach. These data allow us to place Akhalkalaki F.U. in the middle Galerian mammal assemblage. In the central Europe,
Voigtstedt in Germany and Koneprusy in Czech Republic demonstrate the similar stratigraphic position (Koenigswald \& Heinrich, 1999).

Urup F.U. (stratum type - Treugolnaya Cave, layers 6, 7a, and 7b): Canis mosbachensis, Ursus deningeri, Meles hollitzeri, Mustela nivalis, Crocuta spelaea (cf. praespelaea), Panthera spelaea, Equus altidens, Stephanorhinus hundsheimensis, Capreolus cf. suessenbornensis, Cervus elaphus, Bison schoetensacki (Baryshnikov, 1993, with additions).

I have earlier established the Urup local fauna for the lower layers of Treugolnaya Cave, which is located near Urup River in the Karachai-Cherkess Republic in the Northern Caucasus at height 1510 ma.s.l. (Baryshnikov, 1993). The layer 7a was dated by the electron-paramagnetic resonance technique (EPR) $583000 \pm 25000$ (Doronichev, 1991; Molodkov, 2001). The species association in the layers $6,7 \mathrm{a}$, and $7 \mathrm{~b}$ indicates both the cold and warm climatic phases, which may be linked with isotopic stages 13-15. Paleomagnetic analysis indicates that these horizons were deposited during the Brunhes Normal Chron and postdate 780000 years ago (Pospelova et al., 1996).

Other localities. Transcaucasia (Azykh Cave, layer 6): Vulpes vulpes, Ursus aff. arctos, Panthera pardus, Lynx issidorensis, Stephanorhinus kirchbergensis, Equus 
cf.suessenbornensis, Equus hydruntinus, Sus sp.,Megaloceros giganteus, Damacf. mesopotamica (determined by D. Gadzhiev and A. Aliev; Suleimanov, 1982; Lioubine, 1998). Northern Caucasus: Mammuthus trogontherii (Girei quarry, lower level) (Vereshchagin, 1959).

In the Western Europe, the similar species combination is typical of the late Galerian fauna - Fontana Raniccio F.U. in Italy (Gliozziet al., 1997), Miesenheim 1, Mosbach 2, Mauer, and Erpfingen 1 in Germany and Hundsheim in Austria (Koenigswald \& Heinrich, 1999).

\section{Aurelian Mammal Age}

In the Eastern Europe, this faunal assemblage is associated with the late Singilian, Khazarian, Shkurlatian and the Upper Paleolithic (Mammoth) mammal complexes (Alexeeva, 1977, 1990).

Kudaro F.U. (stratum type - Kudaro 1 Cave, layer 5c): Macaca sp.,Homo sp., Vulpes vulpes, Cuon alpinus (?), Canis sp. (cf. C. latrans), Canis mosbachensis, Ursus thibetanus mediterraneus, Ursus deningeri praekudarensis, Meles meles, Martes foina, Vormela peregusna, Mustela nivalis, Panthera pardus, Panthera gombaszoegensis, Lynx lynx, Felis silvestris, Stephanorhinus hundsheimensis, Cervus elaphus, Capreolus capreolus, Alces alces (?), Megaloceros sp., Bison sp., Soergelia sp., Rupicapra rupicapra, Capra caucasica, Ovis cf. ammon (determined by the author).

This faunal unit has been recognized for the lower Acheulean layer 5c in Kudaro 1 Cave, situating in the Dzhodzhori River valley near Kvaisi town in the northern Georgia at height 1600 m a.s.l. (Baryshnikov, 1993). This layer was dated by radiothermoluminescence method as $360000 \pm 90000$ (RTL-379) (Lioubine, 1998). For the overlaying layer $5 \mathrm{~b}$, the obtained date was 350 $000 \pm 70000$ (RTL-373).

Other localities. Transcaucasia - Azykh Cave (layer 5): Homo sp. (cf. H. heidelbergensis), Canis aureus (?), Felis chaus, Stephanorhinus kirchbergensis, Equus cf. mosbachensis, Equus hydruntinus, Sus scrofa, Megaloceros sp., Dama mesopotamica, Saiga sp., Capra aegagrus (determined by D. Gadzhiev and A. Aliev; Suleimanov, 1982; Lioubine, 1998); Leninakan and Engidzha: Palaeoloxodon antiquus, Mammuthus trogontherii, Camelus knoblochi, Bos trochoceros(Alexeeva, 1977). Northern Caucasus - Treugolnaya Cave (layers 5a-5c, with EPR-data of $393000 \pm 27$ 000; Doronichev, 1991): Bison schoetensacki; Girei quarry (middle level): Mammuthus trogontherii (Vereshchagin, 1959).

In the Western Europe, the same age faunal complexes appear to be those from Torre in Pietra F.U. in Italy (Gliozzi et al., 1997) and Heppenloch, Steinheim and Bilzingsleben 2 in Germany (Koenigswald \& Heinrich, 1999).

Kvaisi F.U. (stratum type - Kudaro 3 Cave, layer 5): Canis lupus, Vulpes vulpes, Ursus thibetanus, Ursus deningeri (transitional form between $U$. d. praekuda- rensis and $U . d$. kudarensis), Meles meles, Panthera spelaea, Panthera pardus, Capreolus capreolus, Cervus elaphus, Bison sp. (determined by the author).

Kudaro 3 Cave is situated adjacent to the Kudaro 1 Cave of the Chasovali Mountain. For the unclear contact of the Acheulean layer 5 and lower level of the Mousterian deposits in Kudaro 3 Cave, the two RTL-dates: 252 $000 \pm 51000$ and $245000 \pm 49000$ are available (Lioubine, 1998). According to these dates and presence of the warm-requiring species Kvaisa F.U. may be correlated to the isotope stage 7.

In the Western Europe, Vitinia F.U. in Italy and Hunas and Weimar-Ehringsdorf in Germany are analogous in age with Kvaisa F.U. (Gliozzi et al., 1997, Koenigswald \& Heinrich, 1999).

Binagady F.U. (stratum type — Binagady): Canis lupus, Vulpes corsac, Vulpes vulpes, Ursus arctos binagadensis, Meles meles, Vormela peregusna, Crocuta spelaea, Panthera spelaea, Acinonyx jubatus, Felis lybica, Equus cf. hydruntinus, Equus hemionus binagadensis, Equus ferus, Stephanorhinus hemitoechus, Sus apscheronicus, Cervus elaphus, Megaloceros giganteus, Bos mastanzadei, Bos primigenius, Saiga tatarica binagadensis, Ovis cf. ammon (Vereshchagin, 1959; Guérin \& Barychnikov, 1987; Eisenmann \& Mashkour, 1999).

Binagady locality is situated in environs of Baku in Azerbaijan and represents an asphalt trap, in which the large and small mammal bones were accumulated. The locality age is not determined exactly, however it is usually associated with the age of the Shkurlatian mammal complex in the Eastern Europe correlated to the latest Interglacial (=Eem in the Western Europe) (Alexeeva, 1990).

Other localities. Transcaucasia (Kudaro 3, layer 4f): Ursus thibetanus, Ursus deningeri kudarensis, Capreolus capreolus, Cervus elaphus, Bison sp., Capra caucasica (determined by the author). Northern Caucasus (Girei quarry, upper level, Ilskaya 2, layer 7, Krasnodar, Matuzka Cave, layer 6): Ursus rossicus, Mustela nivalis, Palaeoloxodon antiquus, Mammuthus primigenius (early form), Stephanorhinus sp., Coelodonta antiquitatis (Borissiak, 1932; Vereshchagin, 1959; Baryshnikov \& Golovanova, 1989; Alexeeva, 1990).

In Germany, Burgtonna and Taubach localities have the similar age (Koenigswald \& Heinrich, 1999).

Chasovali F.U. (stratum type - Kudaro 3 Cave, layer 3): Vulpes vulpes, Cuon alpinus caucasicus, Canis lupus, Ursus arctos, Ursus deningeri kudarensis (earlier form), Meles meles, Martes foina, Martes martes, Vormela peregusna, Mustela nivalis, Panthera pardus, Panthera spelaea, Lynx lynx, Felis silvestris, Capreolus capreolus, Cervus elaphus, Rupicapra rupicapra, Capra caucasica (determined by the author). Hemitragus sp. found in Kudaro 1 Cave may be added to this complex (determined by E. Crégut).

The composition of this faunal unit is well known by collections from numerous Mousterian sites situated on the northern and southern slopes of the Greater Cauca- 
sus. The layer 3 a of Kudaro 1 Cave has radiocarbon date $44100 \pm 2400.1850$ (Gr-6079) (Lioubine, 1989).

Other localities. Transcaucasia: Homo neanderthalensis, Crocuta spelaea, Equus ferus, Equus hydruntinus, Stephanorhinus hundsheimensis(Erevan),Sus scrofa, Megaloceros giganteus, Alces alces, Bison priscus, Gazella subgutturosa, Capra aegagrus, Ovis ammon (Vekua, 1978; Dzhafarov, 1983; Lioubine, 1989; Guérin et al., 1992). Vekua (1978) cited provisionally for Verkhnyaya Cave in Georgia also Canis aureus. Northern Caucasus: Ursus spelaeus (Ilskaya 1), Mammuthus primigenius, Equus hydruntinus, Equus ferus taubachensis(Ilskaya 2, layer 5), Rangifer tarandus (Mezmaiskaya Cave), Saiga tatarica, Ovis orientalis (Baryshnikov \& Hoffecker, 1994) and possibly Coelodonta antiquitatis (Vereshchagin, 1959).

Faunal lists of Transcaucasian sites generally contain cave bear assigned to Ursus spelaeus. However, the study of the cave bear remains from Mousterian levels in Kudaro 1 and 3 caves and Akhstyrskaya Cave revealed its archaic dentition, resembling that of Ursus deningeri from Europe (Baryshnikov, 1998). It is quite possible that finds from Transcaucasia belong to $U$. deningeri kudarensis, while $U$. spelaeus occurred in the Northern Caucasus only.

Akhstyr F.U. (stratum type - Akhstyrskaya Cave, layer 2, lower part): Homo sapiens, Vulpes vulpes, Ursus deningeri kudarensis (later form), Sus scrofa, Alces alces, Capreolus capreolus, Cervus elaphus, Capra caucasica (Gromova, 1948, with additions).

Akhstyrskaya Cave is situated near Sochi City and located at height $280 \mathrm{~m}$ a.s.l. For the middle part of the layer 2 the radiocarbon date $19500 \pm 500$ has been obtained (Lioubine, 1989).

Other localities: Canis lupus, Ursus arctos, Meles meles, Martes foina, Gulo gulo (Gvardzhilas-Klde), Mustela erminea (Matuzka), Mustela nivalis, Panthera spelaea, Lynx lynx, Equus ferus strictipes, Equus hydruntinus (Sakazhia), Bos primigenius, Bison priscus, Bison bonasus, Rupicapra rupicapra, Ovis orientalis (Vereshchagin, 1959; Burchak-Abramovich \& Burchak, 1982; Baryshnikov \& Golovanova, 1989; Lioubine, 1989).

This local fauna contains mainly the recent species with small addition of extinct species (Ursus deningeri kudarensis, Panthera spelaea, Equus hydruntinus, Bison priscus) which did not occur in the Holocene. In contrast with the Mousterian fauna, this species composition does not contain Mammuthus primigenius, Coelodonta antiquitatis, and Megaloceros giganteus.

\section{Small mammals}

The data on fossil small mammals from the Caucasus are rather scarce in comparison with that on large mammals, belonging mainly to rodents and lagomorphs. The records of bats are occasional. The insectivore examination being recently begun is still revealing the recent genera in the Pleistocene fauna (Erinaceus, Talpa, Crocidura, Neomys, Sorex).

\section{Galerian Mammal Age}

Akhalkalaki F.U.: Erinaceus sp., Lepus sp., Spermophilus aff.citellus, Marmota longipes (Vekua, 1987).

Other localities. Transcaucasia (Azykh Cave, layers 7-10, within those the boundary between Matuyama and Brunhes paleomagnetic zones has been found by Velichko et al., 1980): Allactaga ex gr. williamsi, Microtus ex gr. arvalis-socialis (Markova, 1982).

Markova (1982) believed that the rodent fauna from the basic layers of Azykh Cave cannot be dated earlier than the Tiraspolian mammal complex in the Eastern Europe. In Italy Microtus (Microtus) aff. arvalis had appeared in the middle Galerian mammal assemblage (Slivia F.U.) (Gliozzi et al., 1997).

The more precise dating of Akhalkalaki F.U. requires the additional micromammal fossil record.

Urup F.U.: Drepanosorex sp. (determined by M. Zaitsev), Ochotona transcaucasica, Spalax sp., Apodemus sp., Ellobius sp., Mesocricetus sp., Clethrionomys sp., Lagurus transiens, Eolagurus luteus volgensis, Arvicola cantianus, Chionomys gud, Terricola ex gr. majori, Microtus cf. arvalis (determined by the author).

The teeth of Arvicola cantianus are small, exhibiting a slight inversion of the enamel thickness. By the size, these teeth enter the zone of transgression between $A$. cantianus and Mimomys savini. In the Eastern Europe, the voles of this evolutionary level are poorly known, presumably being closely related with those from the early Singilian mammal complex of the Eastern Europe (Bolshaya Kamyshevakha) (Rekovets, 1990). In Germany, this level is represented by $A$. cantianus from Mosbach, Mauer, and Petersburch 1 (Koenigswald \& Heinrich, 1999).

Other localities. Transcaucasia (Azykh, layer 6): Mesocricetus ex gr. raddei, Ellobius ex gr. lutescens (Markova, 1982).

\section{Aurelian Mammal Age}

Kudaro F.U.: Erinaceus sp., Rhinolophus ferrumequinum, Rhinolophus mehelyi, Myotis blythi, Myotis nattereri, Vespertilio cf.murinus, Miniopterus schreibersi, Lepus europaeus gureevi, Castor fiber, Hystrix indica, Hystrix vinogradovi kudarensis, Apodemus sp., Cricetulus migratorius argyropuloi, Mesocricetus raddei planicola, Prometheomys schaposchnikovi palaeokudarensis, Clethrionomys cf. glareolus, Arvicola cantianus, Chionomys gud, Chionomys roberti, Terricola ex gr. majori, Terricola $\mathrm{cf}$. arvalidens, Microtus arvalis (Gadzhiev, 1980; Baryshnikov \& Baranova, 1983; Averianov \& Baryshnikov, 1992; with additions).

The teeth of Arvicola cantianus from the Kudaro F.U. are somewhat larger than those of specimens from the Urup F.U., the enamel differentiation being similar. The same features show the voles from Holstein (=Likhvin) faunas both of the Eastern Europe (Gunki, Chigirin, Pivikha) and the Western Europe (Petersburch 1, Bilzingsleben 2, Neede) (Rekovets, 1990; Markova, 1996). 
Other localities. Transcaucasia: Ochotona transcaucasica, Ochotona azerica, Marmota sp., Alactagulus acontion, Allactaga sp., Mus musculus, Apodemus sylvaticus, Meriones erythrourus, Ellobius ex gr. lutescens, Lagurus sp., Microtus ex gr. arvalis-socialis (Markova, 1982; Vekua et al., 1987). Northern Caucasus (Treugolnaya Cave, layers 5a-5c): Spermophilus sp.,Spalax sp.,Ellobius sp.,Lagurus transiens, Eolagurus luteus volgensis (determined by the author).

Kvaisi F.U.: Lepus europaeus gureevi, Hystrix vinogradovi kudarensis, Apodemus uralensis, Cricetulus migratorius argyropuloi, Mesocricetus raddei planicola (Baryshnikov \& Baranova, 1983; Averianov \& Baryshnikov, 1992). This group may also include Marmota paleocaucasica, Chionomyscf.nivalis, Terricola daghestanicus recorded in Kudaro 1 Cave (layer 5a) (determined by the author).

Other localities. Northern Caucasus (Treugolnaya Cave, layers 4b-4c; Matuzka Cave, layer 7): Rhinolophus ferrumequinum, Dryomys nitedula, Cricetulus migratorius guamensis, Cricetus cricetus, Clethrionomys cf.glareolus, Arvicola terrestris chosaricus, Chionomys gud, Chionomys roberti, Terricola majori (Baryshnikov \& Golovanova, 1989; Nadachowski \& Baryshnikov, 1991;with additions).

In the Eastern Europe, the same age rodent fauna is known from the Kamenka Interglacial (Priluki, Chernyi Yar, Rasskazovo) (Markova, 1990, 1996).

Binagady F.U.: Lepus europaeus gureevi, Hystrix vinogradovi vinogradovi, Dryomys nitedula, Allactaga jaculus bogatschewi, Allactaga williamsi dzhafarovi, Allactaga elator, Mus musculus, Apodemus uralensis, Mesocricetus raddei planicola, Cricetulus migratorius argyropuloi, Meriones erythrourus intermedius, Ellobius aff. lutescens, Terricola apsheronicus, Microtus socialis, Microtus arvalis (Gromov, 1952).

Other localities. Northern Caucasus (Matuzka Cave, layer 6): Spermophilus cf. musicus, Spalax microphtalmus, Cricetulus migratorius guamensis, Cricetus cricetus, Arvicola terrestris chosaricus, Chionomys gud, Chionomys roberti, Terricola majori, Terricola daghestanicus (Baryshnikov \& Golovanova, 1989).

In the Western Europe the same age rodent fauna came from the Mikulino Interglacial (Ceremoshnik, Borisova Gora, Ulovka) (Markova, 1990).

Chasovali F.U.: Myotis blythi, Myotis nattereri, Vespertilio cf. murinus, Miniopterus schreibersi, Lepus europaeus (transitional form between L. e. gureevi and recent L. e. cyrensis), Marmota paleocaucasica, Hystrix vinogradovi kudarensis, Dryomys nitedula, Allactaga euphratica, Apodemus uralensis, Cricetulus migratorius, Cricetus cricetus, Mesocricetus raddei planicola, Ellobius lutescens, Prometheomys schaposchnikovi palaeokudarensis, Arvicola terrestris chosaricus, Chionomys gud, Terricola majori fokanovi, Terricola daghestanicus, Microtus arvalis (Gadzhiev, 1980; Baryshnikov \& Baranova, 1983; Averianov \& Baryshnikov, 1992).

Other localities. Transcaucasia: Myotis sp., Eptisicus sp., Ochotona transcaucasica, Spermophilus xan- thoprymnus, Castor fiber, Meriones sp. (Vekua, 1978; Lioubine, 1989). Northern Caucasus: Ochotona pusilla liubine, Lepus capensis, Lepus europaeus, Spermophilus cf. musicus, Sicista sp., Spalax microphtalmus, Apodemus flavicollis, Cricetulus migratorius guamensis, Chionomys nivalis, Chionomys roberti (Baryshnikov \& Golovanova, 1989; Nadachowski \& Baryshnikov, 1991; Averianov \& Baryshnikov, 1992).

Akhstyr F.U.: Sorex satunini, Sorex volnuchini, Apodemus cf. uralensis, Cricetus cricetus, Prometheomys schaposchnikovi, Arvicola terrestris, Chionomys roberti, Terricola majori, Microtus arvalis (determined by the author and M. Zaitsev).

Other localities. Transcaucasia:Marmota paleocaucasica, Castor fiber, Dryomys nitedula, Allactaga williamsi, Cricetulus migratorius, Mesocricetus raddei, Chionomys nivalis, Chionomys gud, Terricola majori, Terricola daghestanicus (Baryshnikov \& Baranova, 1983; Lioubine, 1989; Nadachowski \& Baryshnikov, 1991). Northern Caucasus (Matuzka Cave): Crocidura gueldenstaedti, Spermophilus musicus, Spalax microphtalmus, Chionomys nivalis (Baryshnikov \& Golovanova, 1989).

\section{Conclusions}

The four faunal units (Akhalkalaki, Urup, Kudaro, Kvaisi), characterizing the stages of the Caucasian mammal fauna development in the Middle Pleistocene, are well synchronized with those known for Italy (Isernia, Raniccio, Torre in Pietra, and Vitinia respectively). In the Caucasus, small mammals better indicate the stratigraphic limits for local complexes because some species of large mammals (Ursus deningeri, Panthera gombaszoegensis, Stephanorhinus hundsheimensis) survived in Transcaucasia longer than in Europe due to the more favorable environmental conditions. Chronosubspecies established by the data on evolutionary mammal dental changes allowed me to subdivide the Late Pleistocene Caucasian mammal complex in three faunal units (Binagady, Chasovali, Akhstyr) (see Table).

In the Caucasus, 34 species of large mammals and about 16 species of rodents have been recorded from the Middle Pleistocene. The better known Late Pleistocene fauna includes up to 50 species of large mammals as well as 40 species of rodents. An overwhelming majority of the Caucasian species has been also found in the Western Europe, only some of them being the Caucasian mountain endemics (Ochotona transcaucasica, Prometheomys schaposchnikovi, Terricola majori, Terricola daghestanicus) or came from Asian semi deserts (Hystrix indica, Acinonyx jubatus, Equus hemionus, Camelus knoblochi, Gazella subgutturosa).

There are noticeable zoogeographic differences between the Northern Caucasus and the Transcaucasia. The fauna of latter contained warm-requiring species (Macaca sp., Hystrix indica, Ursus thibetanus, Hippopotamus georgicus), which were not found in the Northern Caucasus. This area, in contrast, includes cold resis- 
tant steppe species (Ochotona pusilla, Cricetus cricetus, Spalax microphtalmus, Ursus rossicus) and boreal species (Mammuthus primigenius, Coelodonta antiquitatis, Rangifer tarandus). At the same time, the typical Arctic mammals (Dicrostonyx, Lemmus, Stenocranius, Alopex, Ovibos) were not recorded there.

Certainly, the Greater Caucasian Ridge covered with strong glaciers during the Pleistocene has been an important barrier preventing the faunal interchange between the Northern Caucasus and Transcaucasia. Therefore, steppe and boreal mammals might occasionally come to the south along the Caspian Sea coast (Saiga tatarica, Equus hydruntinus) or through the lower mountain passes in the central part of the Caucasian Ridge (Cricetus cricetus, Gulo gulo, Mammuthus primigenius). The spatial differentiation of the Transcaucasian Pleistocene fauna has corresponded to the recent one; the forest species being predominated in the west, the semi desert mammals in the east.

ACKNOWLEDGEMENTS. In preparing the manuscript, I was assisted by Svetlana Baryshnikova (Saint Petersburg). I am grateful also to Dr. A. Averianov (Saint Petersburg) for editing the paper.

The work was fulfilled with the financial support of the Russian Foundation for Basic Research (RFBR), grants 0004-48452 and 01-06-80187a, and the State Scientific and Technical Program "Biodiversity".

\section{References}

Aguirre E. \& Pasini G. 1985. The Pliocene-Pleistocene boundary // Episodes. Vol.8. P.116-120.

Alexeeva L.I. 1977. [Early Anthropogene theriofauna of East Europe] // Trudy Geologicheskogo Instituta RAN. Vol.300. P.1-216 [in Russian].

Alexeeva L.I. 1990. [Late Pleistocene theriofauna of East Europe (large mammals)] // Trudy Geologicheskogo Instituta RAN. Vol.455. P.1-109 [in Russian].

Averianov A.O. \& Baryshnikov G.F. 1992. [Pleistocene hares of the genus Lepus (Lagomorpha) in the Greater Caucasus] // Trudy Zoologicheskogo Instituta RAN. Vol.246. P.4-28 [in Russian, with English summary].

Azzaroli A. 1983. Quaternary mammals and the "End-Villafranchian" dispersal event - a turning point in the history of Eurasia // Palaeogeography, Palaeoclimatology, Palaeoecology. Vol.44. No.1-2. P.117-139.

Azzaroli A., De Giuli C., Ficcarelli G. \& Torre D. 1982. Table of stratigraphic distribution of terrestrial mammalian faunas in Italy from the Late Pliocene to early Middle Pleistocene // Geographia Fisica e Dinamica Quaternaria, Torino. T.5. P.55-58.

Baryshnikov G.F. 1989. Les mammifères du Paléolithique inférieur du Caucase // L'Anthropologie (Paris). T.93. No.4. P.813-830.

Baryshnikov G.F. 1993. [Large mammals of the Acheulean site in the Treugolnaya Cave of the Northern Caucasus] // Trudy Zoologicheskogo Instituta RAN. Vol.249. P.347 [in Russian, with English summary].

Baryshnikov G.F. 1998. Cave bears from the Paleolithic of the
Greater Caucasus // Illinois State Museum Scientific Papers. Vol.17. P.69-118.

Baryshnikov G.F. \& Baranova G.I. 1983. [Rodents from the early Paleolithic of the Greater Caucasus] // Trudy Zoologicheskogo Instituta AN SSSR. Vol.119. P.100-138 [in Russian].

Baryshnikov G.F. \& Hoffecker J. 1994. Mousterian hunters of the NW Caucasus: preliminary results of recent investigations // Journal Field Archaeology. Vol.21. P.1-14.

Baryshnikov G.F. \& Golovanova L.V. 1989. [Mammals of the Mousterian site Matuzka in the Kuban Caucasus] // Trudy Zoologicheskogo Instituta RAN. Vol.198. P.3-55 [in Russian, with English summary].

Baryshnikov G.F. \& Vereshchagin N.K. 1996. [A brief review of Quaternary hyenas (Hyaenidae) of Russia and adjoining regions] // Trudy Zoologicheskogo Instituta RAN. Vol.270. P.7-65 [in Russian, with English summary].

Borissiak A.A. 1932 (1931). [New race of cave bear from Quaternary of the Northern Caucasus] // Trudy Paleozoologicheskogo Instituta AN SSSR. T.1. P.137-202 [in Russian, with German summary].

Burchak-Abramovich N.I. \& Burchak D.N. 1982. [Pleistocene and early Holocene vertebrate fauna in karst of the Caucasus] // Tsagareli A.L. (ed.). Chetvertichnaya Sistema Gruzii. Tbilisi: Metsniereba. P.150-167 [in Russian].

Doronichev V.B. 1991. [Oldest site an Kuban River] // Drevnosti Kubani. Krasnodar. P.38-41 [in Russian].

Dzhaparidze V., Bosinski G., Bugianishvili T., Gabunia L., Justus A., Klopotovskaya N., Kvavadze E., Lordkipanidze D., Majsuradze G., Mgeladze N., Nioradze M., Pavlenishvili E., Schmincke H.-U., Sologashvili D., Tushabramishvili D., Tvalchrelidze M. \& Vekua A. 1989. Der altpalaolitische fundplatz Dmanisi in Georgien (Kaukasus) // Jahrbuch des römisch-germanischen Zentralmuseums, Mainz. Jhg.36. S.67-116.

Dzhafarov A.K. 1983. [Mousterian culture of Azerbaijan]. Baku: Elm. 99 p. [in Russian].

Eisenmann V. \& Mashkour M. 1999. The small equids of Binagady (Azerbaijan) and Quazvin (Iran): E. hemionus binagadensis nov. subsp. and E. hydruntinus // Geobios. T.32. No.1. P.105-122.

Gadzhiev D.V. 1980. [Chiroptera remains from Kudaro 1 Cave] // Ivanova I.K. \& Chernyakhovski A.G. (eds.). Kudarskie Peshchernye Paleoliticheskie Stoyanki v YugoOsetii. Moskva: Nauka. P.111-124 [in Russian].

Gliozzi E., Abbazzi L., Argenti P., Azzaroli A., Caloi L., Capasso Barbato L., di Stefano G., Esu D., Ficarelli G., Girotti O., Kotsakis T., Masini F., Mazza P., Mezzabotta C., Palombo M.R., Petronio C., Rook L., Sala B., Sardella R., Zanalda E. \& Torre D. 1997. Biochronology of selected mammals, mollusks and ostracods from the Middle Pliocene to the Late Pleistocene in Italy // Rivista italiana di paleontologia e stratigraphia. T.103. No.3. P.369-388.

Gromov I.M. \& Fokanov V.A. 1980. [Late Pleistocene rodents remains from Kudaro 1 Cave] // Ivanova I.K. \& Chernyakhovski A.G. (eds.). Kudarskie Peshchernye Paleoliticheskie Stoyanki v Yugo-Osetii. Moskva: Nauka. P.79-89 [in Russian].

Gromova V.I. 1948. [About the history of the Caucasian 
mammals] // Izvestiya Akademii Nauk SSSR. Seriya Biologicheskaya. T.5. P.516-537 [in Russian].

Guérin C. 1996. Famille des Equidae // Guérin C. \& PatouMathis M. (eds.) Les grandes mammifères Plio-Pleistocene d'Europe. Paris: Masson. P.121-131.

Guérin C. \& Barychnikov G.F. 1987. Le rhinocéros acheuléen de la grotte de Koudaro 1 (Géorgie, URSS) et le problème des espèces relicts du Pléistocène du Caucase // Geobios. T.20. No.3. P.389-396.

Guérin C., Barychnikov G.F. \& Mejloumian S.K. 1992. Survivance tardive d'une forme archąque dans le Pleistocène du Caucase: le Dicerorhinus etruscus brachycephalus du gisement moustérien d'Erivan I (Arménie) (Mammalia, Rhinocerotidae) // Bulletin mensuel de la Societe linnéenne de Lyon. T.61. No.6. P.166-174.

Koenigswald W. von \& Heinrich W.-D. 1999. Mittelpleistozäne Säugetierfaunen aus Mitteleuropa - der Versuch einer biostratigraphischen Zuordnung // Kaupia. Bd.9. S.53-112.

Lioubine V.P. 1989. [The Paleolithic of the Caucasus] // Boriskovskii P.I. (ed.). Paleolit Kavkaza i Severnoi Azii. Leningrad: Nauka. P.7-142 [in Russian].

Lioubine V.P. 1998. [The Acheulean epoch in the Caucasus] // Archeologicheskie Studii, Saint Petersburg. T.47. No.1. P.1-192 [in Russian].

Markova A.K. 1982. [Small mammals from the Paleolithic site in Azykh Cave] // Paleontologicheskii Sbornik, L'vov. No.19. P.14-28 [in Russian, with English summary].

Markova A.K. 1990. Pleistocene microtheriofauna of the European part of the USSR // Fejfar O. \& Heinrich W.-D. (eds.). International Symposium of Evolution, Phylogeny and Biostratigraphy of Arvicolids, Praha. P.313-338.

Markova A.K. 1996. Late Middle Pleistocene small mammal faunas from the Russian Plain and their analogs from western Europe // Acta Zoologica Cracoviensia. Vol.39. No.1. P.311-319.

Mazza P. 1991. Interrelations between Pleistocene hippopotami of Europe and Africa // Bolletino della Societá paleontologica italiana. Vol.30. No.2. P.153-186.

Molodkov A.N. 2001. ESR dating for early man at a Lower Paleolithic cave-site in the Northern Caucasus as derived from terrestrial mollusk shells // Quaternary Science Reviews. Vol.20. P.1051-1055.

Nadachowski A. \& Baryshnikov G.F. 1991. Pleistocene snow voles (Chionomys Miller, 1908) (Rodentia, Mammalia) from Northern Caucasus (USSR) // Acta Zoologica Cracoviensia. Vol.34. No.2. P.437-451.

Nesmeyanov S.A. 1999. [Geomorphological aspects of Paleolithic palaeoecology of the Western Caucasus]. Moskva: Nauchnyi Mir. 392 p. [in Russian].
Petronio C. \& Sardella R. 1999. Biochronology of the Pleistocene mammal fauna from Ponte Galeria (Rome) and remarks on the Middle Galerian faunas // Rivista italiana di paleontologia e stratigraphia. T.105. No.1. P.155-164. Pospelova G.A., Sharonova Z.V., Mironov T.V. \& Levkovskaya G.M. 1996. Paleomagnetic study and climatic record in sedimentary rocks of the Treugolnaya Cave, Northern Caucasus // Physics of the Solid Earth. Vol.32. No.9. P.754-765.

Rekovets L.I. 1990. Principal developmental stages of the water vole genus Arvicola (Rodentia, Mammalia) from the Eastern European Pleistocene // Fejfar O. \& Heinrich W.D. (eds.). International Symposium of Evolution, Phylogeny and Biostratigraphy of Arvicolids, Praha. P.369-384.

Shackleton N.J. 1995. New data on the evolution of Pliocene climatic variability // Paleoclimate and Evolution with Emphasis on Human Origins. London: Yale University Press. P.242-248.

Shackleton N.J. \& Opdyke N.D. 1976. Oxygen isotope and palaeomagnetic stratigraphy of Pacific core V.28-239. Late Pliocene to latest Pleistocene // Memoirs of the Geological Society of America. No.145. P.449-464.

Suleimanov M.B. 1982. Environment of Paleolithic man in southeast of the Lesser Caucasus. Avtoreferat Kandidatskoi Dissertatsii. Moskva. 23 p. [in Russian].

Vekua A.K. 1962. [The Lower Pleistocene fauna of mammals of Akhalkalaki]. Tbilisi: Izdatel'stvo Akademii Nauk Gruzinskoi SSR. 207 p. [in Georgian, with Russian summary]

Vekua A.K. 1978. [Fossil vertebrate from Tsutskhvati caves] // Davitaya F.F. (ed.). Izuchenie Peshcher Kolkhidy. Tbilisi: Metsniereba. P.94-126 [in Russian].

Vekua A.K. 1987. The Lower Pleistocene mammalian fauna of Akhalkalaki (southern Georgia, USSR) // Palaeontographica italiana. Vol.74. P.63-96.

Vekua A.K. 1995. Die Wirbeltierfauna des Villafranchium von Dmanisi und ihre biostratigraphische Bedeutung // Jahrbuch des römisch-germanischen Zentralmuseums, Mainz. Jhg.42. S.1-180.

Vekua A.K., Gabelaya T.D., Muskhelishvili A.T. \& Mamatsashvili N.S. 1987. [Paleolithic Vertebrata fauna of the Tsona Cave] // Peshchery Gruzii. No.11. P.92-100 [in Russian].

Velichko A.A., Antonova G.V., Zelikson E.M. et al. 1980. [Paleography of Azykh - oldest Paleolithic site in USSR territories] // Izvestiya Akademii Nauk SSSR. Seriya Geographicheskaya. No.3. P.20-35 [in Russian].

Vereshchagin N.K. 1959. Mammals of the Caucasus. Moskva-Leningrad: Izdatel'stvo Akademii Nauk SSSR. 704 p. [in Russian]. 